\title{
Exchange Rate Policy Tensions: A Comparative Study between North Africa and Central \& Eastern Europe
}

\author{
Ali Massoud $^{1,2} \&$ Julius Horvath ${ }^{3}$ \\ ${ }^{1}$ Sohag University, Egypt. \\ ${ }^{2}$ Visiting fellow at Central European University, Hungary. \\ ${ }^{3}$ Central European University, Hungary. \\ Correspondence: Ali Massoud, Sohag University, Sohag, Egypt.
}

Received: July 2, 2015

doi:10.11114/aef.v2i4.1030
Accepted: July 15, 2015

Available online: August 10, 2015

\begin{abstract}
The performance of small open economies depends - to an extent - on the tension between government's economic policy preferences and actual behavior. This tension can be nicely studied by analyzing the behavior of exchange rates, where one observes tensions between proclaimed de jure and de facto exchange rate policies. Typically a country makes a de jure commitment to a peg if it attempts to persuade markets of its strict monetary-policy priorities; similarly a country makes a de jure commitment to a float if it wants to keep monetary policy in its own hands. In this paper we measure the flexibility of exchange rate which partially helps in deciphering the de facto behavior. For this purpose, we use comparative data of two sets of countries: North African as well as Central and Eastern European.
\end{abstract}

Keywords: Exchange rate policy, de facto exchange rate regimes, and exchange market pressure

\section{Introduction}

Researchers had observed a discrepancy between de facto and de jure exchange rate regimes. For example, in countries that claim that exchange rate regime is a peg, currencies do not behave as fixed. Similarly, often under different versions of the floating regime it seems as if the domestic currency would not float. Also at times it is difficult to estimate the weight of individual currencies if countries introduced peg to a basket of currencies.

The idea is that one investigates the behavior of foreign exchange rate reserves together with the behavior of the exchange rate. If country introduces pure float, one expects no government intervention, i.e. one expects zero variability of the foreign exchange reserves and (not necessarily but predominantly) high variability of the exchange rate. It happens that in floating countries the variability of foreign exchange reserves relative to the variability of their exchange rate regime is similar as in countries which introduced pegged regimes. In recent years one observes that countries introducing Inflation Targeting together with float quite intervened to prevent appreciation of their currencies, for example stemming from the Balassa-Samuelson pressures.

This paper deals with exchange rate regimes of two sets of countries: five Eastern and Central European countries (Croatia, the Czech Republic, Hungary, Poland, and Romania) and three North African countries (Algeria, Egypt, and Tunisia).1 The point of our interest is estimation with a relatively recent technique analyzing behaviour of exchange rates introduced by Frankel and Wei (2008 and 2009). This technique helps to guide us whether in the given set countries de facto regimes are actually identical or similar to the de jure exchange rate regimes.

We structure our paper in the typical way. After some short theoretical discussion, we present the methodology and the results of estimation. Finally, we summarize and conclude.

\section{Theoretical Discussion}

Classification of exchange rate regimes is a complicated issue. 2 De jure classification is the most natural one and

\footnotetext{
${ }^{1}$ We left out from our sample countries as the Slovak Republic, Slovenia, Bulgaria, and Baltic countries as they are euro area members and/or work with fixed exchange rate regimes (currency board) for a relatively long period. We had also left out two Maghreb countries - Libya and Morocco because both countries follow conventional peg. Also in some of these countries data were not fully available.

${ }^{2}$ See Horvath (2006) for a more detailed view.
} 
shows the intention of the governments. However, the behavior of the government might not follow their own intention, and this creates the basis for the de facto exchange rate regime being different. This section sheds lights on some aspects of theory of de jure exchange rate regime choice. We differentiate five types of approaches to choosing of exchange rate regime. First, it is the classical approach; one takes a macroeconomic model and evaluates which exchange rate regime could ease the response of the economy to different disturbances. Second approach emerged in discussions about exchange rate regimes in the context of stabilization plans. Third approach originates from the time inconsistency literature and puts the credibility versus flexibility trade-off into the center. Fourth, is the optimum currency area approach and fifth considers ex post macroeconomic performance under different exchange rate regimes and explores what was the effect of these different exchange rate regimes on basic macro variables and consequently adjust the exchange rate regime.

These five approaches assumed that when choosing exchange rate regimes countries have all possible options available. However, from the 1990s - after the series of currency crisis - new concepts evolved arguing that options given to countries are limited. In other words in times of speculative attacks an idea emerged that to prevent speculative attacks countries should opt for the corner solutions.3 However, on the other hand literature emerged on the 'fear of floating', as in Calvo and Reinhart (2002).

Attempts to classify countries according to de facto exchange rate regime emerged and Bubula and Ötker-Robe (2002), Reinhart and Rogoff (2004) and Levy-Yeyati and Sturzenegger (2005) are the most important contributions in this area. ${ }^{4}$

One can understand the idea of the difference between de facto and de jure exchange rates by concentrating on exchange market pressure. This is currency's excess supply (demand) in the foreign exchange market. For example, if the domestic country is in the floating exchange rate regime then excess supply is expressed in the relative depreciation, which removes the exchange market pressure. However, under other regimes the monetary authorities prevent depreciation by policy measures. Then the actual depreciation does not coincide with exchange market pressure.

Exchange market pressure is unobservable (except for a pure float), needs to be estimated, and this is the subject of the next Section.

\section{Empirical Methodology}

Many studies had introduced statistical measures to identify the de facto exchange rate regimes. For instance, Reinhart and Rogoff (2004) classification has many desirable features such as including inflation and dual exchange rate regimes, however it investigates only the behavior of the exchange rate and not adjusting for the extent of official intervention. Levy-Yeyati and Sturzenegger (2005) use cluster analysis of changes in exchange rates regime but their methodology allows them only to differentiate between fixed, crawling peg, and floating rate regimes and does not provide a method of analyzing the degree of official management of flexible regimes. The approach presented by Calvo and Reinhart (2002) is based on analyses of the variances of changes in reserves, exchange rate, and interest rates. The use of the ratios of variances does not allow considering the extent of management in individual periods of short duration. The use of interest rates is problematic as one cannot easily infer them from statistical data; Massoud and Willett (2014). For a recent and more detailed review of these measures see Willett et al. (2011).

Beside these efforts to introduce statistical measures for de facto exchange rate regimes, the IMF - based on its staff judgments - provides its own classifications for the exchange rate regimes that its member countries follow. The following tables summarize the IMF classifications for the de facto exchange rate regimes in the countries we examine in this paper.

Table 1.The IMF De Facto Classification of Exchange Rate Regimes in some of the Northern African Countries

\begin{tabular}{|c|c|c|c|}
\hline Year/Country & Algeria & Egypt & Tunisia \\
\hline $\begin{array}{l}2014 \\
\text { (April 30) }\end{array}$ & $\begin{array}{l}\text { Other Managed Arrangement } \\
\text { (Composite) }\end{array}$ & $\begin{array}{l}\text { Stabilized Arrangement } \\
\text { (Other) }\end{array}$ & $\begin{array}{l}\text { Crawl-Like Arrangement } \\
\text { (Other) }\end{array}$ \\
\hline
\end{tabular}

\footnotetext{
3 In other words countries should opt to have a truly fixed exchange rate regime - as a currency board or joining the monetary union - or on the other, end of the spectrum a free floating regime. Calvo and Mishkin (2003) call those exchange rate arrangements which were broken as 'soft pegs,' indicating that such arrangements were not sufficient to protect the currency. Eichengreen (1994) made an argument that to prevent future currency crisis either substantially increased flexibility or true rigidity is needed as both regimes might have increased ability to prevent speculative attacks. This began to be called hypothesis of the vanishing intermediate exchange rate regime, or 'bipolar view' or 'corner solutions' to the practical exchange rate arrangements. For example, Frankel, Fajnzylber, Schmukler and Serven (2001) argued that a simple regime (rigid or flexible) is more verifiable by market participants than a complicated intermediate exchange rate regime.

${ }^{4}$ Babula and Otker-Robe (2002) provide empirical evidence, which helps to evaluate the validity of the vanishing intermediate exchange rate proposition. They provide data about percentage representations of different exchange rate regimes across countries. Comparing 1990 to 2001 Babula and Otker-Robe (2002) show that both hard pegs and floating regimes importance has increased. In 1990 hard pegs represented around $15 \%$ of exchange rate arrangements across the world, while in 2001 this has increased to little more than $25 \%$. The increase for floating arrangements was even higher from $15 \%$ to $35 \%$. While we observe a movement towards corner solutions worldwide, this tendency is the most pronounced among the developed and emerging market countries and less among the developing countries.
} 


\begin{tabular}{|c|c|c|c|}
\hline 2013 & $\begin{array}{l}\text { Other Managed Arrangement } \\
\text { Composite) }\end{array}$ & $\begin{array}{l}\text { Crawl-Like Arrangement } \\
\text { (Other) }\end{array}$ & $\begin{array}{l}\text { Crawl-Like Arrangement } \\
\text { (Other) }\end{array}$ \\
\hline $\begin{array}{l}2012 \\
\text { (April 30) }\end{array}$ & $\begin{array}{l}\text { Other Managed Arrangement } \\
\text { (Composite) }\end{array}$ & $\begin{array}{l}\text { Stabilized Arrangement } \\
\text { (Other) }\end{array}$ & $\begin{array}{l}\text { Crawl-Like Arrangement } \\
\text { (Other) }\end{array}$ \\
\hline 2011 & Other Managed Arrangement & $\begin{array}{l}\text { Crawl-Like Arrangement } \\
\text { (Other) }\end{array}$ & $\begin{array}{l}\text { Stabilized Arrangement } \\
\text { (Composite) }\end{array}$ \\
\hline 2010 & Other Managed Arrangement & $\begin{array}{l}\text { Other Managed Arrangement } \\
\text { (Other) }\end{array}$ & $\begin{array}{l}\text { Stabilized Arrangement } \\
\text { (MT) }\end{array}$ \\
\hline
\end{tabular}

Source: IMF, the annual report on exchange arrangements and exchange restrictions. (2010:2014).

Table 2.The IMF De Facto Classification of Exchange Rate Regimes in some Central and Eastern European Countries.

\begin{tabular}{|c|c|c|c|c|c|}
\hline Year/Country & Croatia & Czech & Hungary & Poland & Romania \\
\hline $\begin{array}{l}2014 \\
\text { (April 30) }\end{array}$ & $\begin{array}{l}\text { Crawl-Like } \\
\text { Arrangement } \\
\text { (Euro) }\end{array}$ & $\begin{array}{l}\text { Other Managed } \\
\text { Arrangement } \\
\text { (IT) }\end{array}$ & $\begin{array}{l}\text { Floating } \\
\text { (IT) }\end{array}$ & $\begin{array}{l}\text { Free Floating } \\
\text { (IT) }\end{array}$ & $\begin{array}{l}\text { Floating } \\
\text { (IT) }\end{array}$ \\
\hline 2013 & $\begin{array}{l}\text { Crawl-Like } \\
\text { Arrangement } \\
\text { (Euro) }\end{array}$ & $\begin{array}{l}\text { Free Floating } \\
\text { (IT) }\end{array}$ & $\begin{array}{l}\text { Floating } \\
\text { (IT) }\end{array}$ & $\begin{array}{l}\text { Free Floating } \\
\text { (IT) }\end{array}$ & $\begin{array}{l}\text { Floating } \\
\text { (IT) }\end{array}$ \\
\hline $\begin{array}{l}2012 \\
\text { (April 30) }\end{array}$ & $\begin{array}{l}\text { Crawl-Like } \\
\text { Arrangement } \\
\text { (Euro) }\end{array}$ & $\begin{array}{l}\text { Free Floating } \\
\text { (IT) }\end{array}$ & $\begin{array}{l}\text { Floating } \\
\text { (IT) }\end{array}$ & $\begin{array}{l}\text { Free Floating } \\
\text { (IT) }\end{array}$ & $\begin{array}{l}\text { Floating } \\
\text { (IT) }\end{array}$ \\
\hline 2011 & $\begin{array}{l}\text { Crawl-Like } \\
\text { Arrangement } \\
\text { (Euro) }\end{array}$ & $\begin{array}{l}\text { Free Floating } \\
\text { (IT) }\end{array}$ & $\begin{array}{l}\text { Floating } \\
\text { (IT) }\end{array}$ & $\begin{array}{l}\text { Free Floating } \\
\text { (IT) }\end{array}$ & $\begin{array}{l}\text { Floating } \\
\text { (IT) }\end{array}$ \\
\hline 2010 & $\begin{array}{l}\text { Stabilized } \\
\text { Arrangement } \\
\text { (Euro) }\end{array}$ & $\begin{array}{l}\text { Free Floating } \\
\text { (IT) }\end{array}$ & $\begin{array}{l}\text { Floating } \\
\text { (IT) }\end{array}$ & $\begin{array}{l}\text { Free Floating } \\
\text { (IT) }\end{array}$ & $\begin{array}{l}\text { Floating } \\
\text { (IT) }\end{array}$ \\
\hline
\end{tabular}

Source: IMF, The annual report on exchange arrangements and exchange restrictions. (2010:2014). IT denotes inflation targeting.

In this paper we use the Exchange Market Pressure (EMP) methodology introduced by Frankel and Wei (2008 and 2009) to estimate the degree of the flexibility of the exchange rate regimes for the sample countries.5 This approach investigates the degree to which shifts in demand and supply in the foreign exchange market are allowed to move the exchange rate versus being offset by official intervention. The EMP is defined as the percentage change in the value of the currency plus the change in reserves as a fraction of the monetary base. In this empirical exercise the IMF Special Drawing Right (SDR) is used as a numeraire. To avoid non-stationarity, likely to occur in time series, the variables are used in terms of changes rather than levels.

The Frankel and Wei's methodology that we used to estimate the degree of the flexibility of the exchange rate regimes in the sample countries is based on the following equation:

$$
\Delta \log D C(i) t=C+\sum w(j) \Delta \log X(j) t+\delta\{\Delta \operatorname{emp}(i) t\}+\mu t
$$

\footnotetext{
${ }^{5}$ Similar measurements were done by Reinhart and Rogoff (2004), Levy-Yeyati and Sturzenegger (2005), and Calvo and Reinhart (2002).
} 
In equation (1) $\Delta \log \mathrm{DC}(\mathrm{i}) \mathrm{t}$, in period $\mathrm{t}$, denotes the change of the log value of the domestic currencies of the countries under investigation (DC1,DC2, DC3, ., and DCn) with respect to the SDR. In addition, $\Delta \log \mathrm{X}(\mathrm{j}) \mathrm{t}$ is the change of the $\log$ value of the currencies $(\mathrm{X} 1, \mathrm{X} 2, \ldots$, and $\mathrm{Xn})$ in period t. The coefficient $\mathrm{w}(\mathrm{j})$ represents the de facto weights of the used currencies and it will be w1, w2, .., and wn. Finally, the variable $\Delta$ emp(i)t, is defined in the following way.

$$
\Delta \operatorname{emp}(i) t=\Delta \log D C(i) t+\Delta \operatorname{Res}(i) t / M B(i) t
$$

The variable $\Delta$ emp(i)t denotes the percentage change in the exchange market pressure that is the increase of the net international demand for the domestic currency, DC(i), which may become evident in either the price of the domestic currency or in the change in the quantity of international reserves (Res). The last effect will depend on the policies of the national central banks.

Further, in equation (1), $\delta$ denotes the coefficient that captures the de facto degree of exchange rate flexibility. It takes values between 0 and 1 . If $\delta$ equals to zero this means the value of the domestic currency is fixed. While if $\delta$ equals to one this means that the domestic currency is freely floating. Any number in between represents the degree of flexibility of the currency. We consider the three leading world currencies, the dollar, the euro and the pound (USD, Euro, BP) to represent the weighted basket, as these are currencies affecting our sample countries' international transactions. Thus, we can rewrite equation (1) to be the following.

$$
\Delta \log D C(i) t=C+w 1 \Delta \log U S D t+w 2 \Delta \log E U R O t+w 3 \Delta \log B P t+\quad \delta\{\Delta \operatorname{emp}(i) t\}+\mu t
$$

Regressions (1) and (2) in tables (3:10) show the estimations results of equation (3). We added a constraint on the coefficients for the currencies used in the right-hand side of equation (3), i.e. that these coefficients add up to unity, $\sum$ $w(j)=1$. Simply by subtracting the change of the log value of the British pound from the change of the log values of the domestic countries in the left-hand side and doing the same thing to the change in the log value for the USD and the EURO in the right-hand side. The following equation represent the new restriction we added on regression of equation (3).

$$
[\Delta \log D C(i) t-\Delta \log B P t]=C+w 1[\Delta \log U S D t-\Delta \log B P t]+w 2[\Delta \log E U R O t-\Delta \log B P t]+\delta\{\Delta e m p(i) t\}+\mu t
$$

Regressions (3) and (4) in tables (3:10) show the estimations results of equation (4).

In the following we present the empirical results for the two sets of countries of our interest.

\section{Results of Estimation}

\subsection{North African Countries}

\subsubsection{Algeria}

Since $1995,{ }^{6}$ Algeria's exchange rate policy has aimed at maintaining a stable real exchange rate against a basket of currencies weighted according to the country's main trading partners. In 1995, the managed float regime was implemented. Between 1995 and 1998 the real exchange rate appreciated by more than 20\%; followed by a slight depreciation between 1998 and 2001. Since early 2002, due to the appreciation of the euro against the dollar, the authorities intervened in the foreign exchange market to realign the dinar. In 2003, the dinar slightly appreciated against dollar; Koranchelian (2005).

The central bank strongly influences the nominal exchange rate on the official market. Through its intervention, the Bank of Algeria adjusts periodically the nominal exchange rate so as to achieve its real exchange rate target. Note that (a) hydrocarbon exports account for more than $95 \%$ of total exports; (b) by law, the foreign exchange receipts from hydrocarbon exports have to be converted into dinars directly at the central bank; and (c) capital account transactions are subject to controls; Koranchelian (2005).

The global crisis has had low impact on Algeria which remains financially stable. Pervasive exchange controls, widespread public ownership, and an abundance of domestic funding have protected banks from external shocks; IMF (2014). The current account surpluses supported the dinar, which seems to follow a real effective exchange rate target. One observes a significant parallel market premium reflecting the effects of exchange controls; IMF (2014).

The banking sector is protected from the foreign exchange shocks as lending in foreign currency is prohibited, exporters are basically required to repatriate all export proceeds. Exchange rate shocks have small impact, as banks can only have

\footnotetext{
${ }^{6}$ After the first oil crisis, the Algerian dinar was pegged to a basket of currencies in which dollar played the most important role due to its importance in hydrocarbon export receipts. Strong appreciation of the dollar in the Reagan era led to a strong appreciation of the Algerian dinar (around 50\% in the first half of the 1980s). The second half of the 1980s began with reverse oil shock; the government responded to the erosion of export revenue by borrowing abroad and limiting import, and the dinar depreciated by one third between 1986 and 1988 . Between 1989 and 1991 , the dinar depreciated to counteract the terms of trade losses; Koranchelian (2005).
} 
small open foreign currency positions; IMF (2014).

IMF (2014, p. 27, footnote 15) states that 'The latest Annual Report on the Exchange Rate Arrangement and Exchange Restriction notes that Algeria has a "composite monetary framework" and "other managed exchange rate arrangement" confirming that the policy framework requires further clarification.' This basically means that it is not absolutely clear what is the exchange rate regime in the country, which makes our analysis more useful.

Table 3 presents the results for the Algerian dinar. We estimated the flexibility index for equations (3) and (4) over two periods. The first period is from January 2002 to October 2014. As table (1) shows, the flexibility index for this period was higher than 0.7 with the coefficients for the dollar and for the euro are high. This is compatible with the IMF classification of the exchange rate regime for the dinar, which is classified as a managed exchange rate regime against basket of currencies.

The second period starts on January 2004 to capture the huge devaluation of the dinar by the Bank of Algeria in 2004. As regressions (2) and (4) in table (3) show, there were increases in the coefficients of the dollar and the euro which means more weights were given to these currencies in determining the exchange rate for the dinar in the second period. Moreover, for the two regressions, we found that the flexibility index declined. This indicates a less flexible dinar after 2004.

Table 3. Estimation of the Flexibility Index of the Algerian Dinar

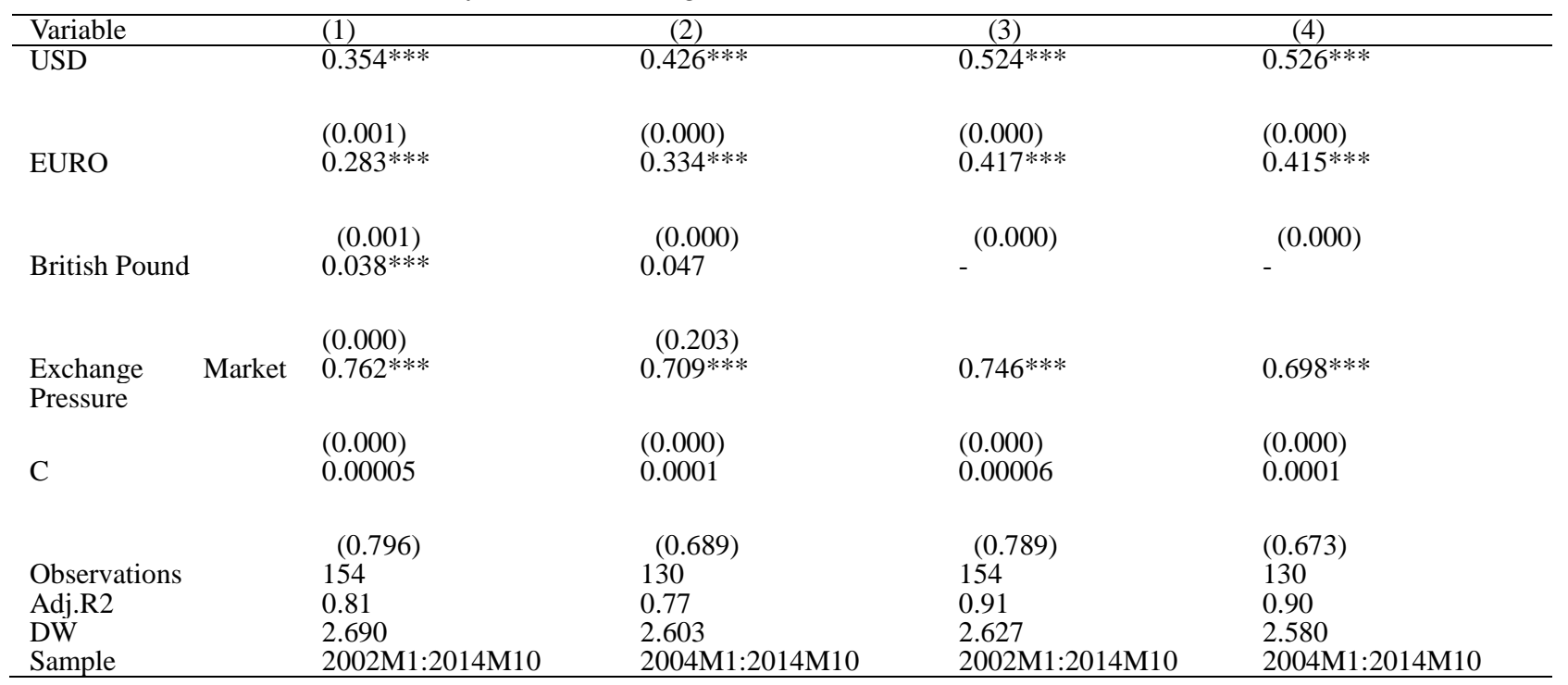

* Statistically significant at 0.1 level, ** Statistically significant at 0.05 level, *** Statistically significant at 0.01 level

Note: numbers in the parenthesis are the $\mathrm{p}$ - values.

\subsubsection{Egypt}

Starting from the sixties till 1990, Egypt had introduced a fixed but adjustable peg in practice. The Egyptian authority had kept the exchange rate of the Egyptian pound fixed to the USD. The Central Bank of Egypt (CBE) had adjusted the Egyptian pound from 1.1 LE per dollar to 2 LE per dollar in July 1990. In February 1991 as a part of the economic reform program, the Egyptian authority changed its exchange rate policy from the adoption of a fixed but adjustable peg to a managed float regime. As a result of the new regime, the Egyptian pound devalued to 3.4 LE per dollar, between February 1991 and December 2000. In January 2001, the CBE announced the adoption of a de jure" Crawling Peg Exchange Rate Regime". Over the period from January 2001 to December 2002, the Egyptian Pound was devalued three times. The first time was when the CBE adopted the new exchange rate regime. At that time the Egyptian pound was set at 3.85 LE per dollar. The second time was on September 2001, as a result of the 9/11 terrorist act against the USA and its implications on the Egyptian economy. The CBE devalued the Egyptian pound to 4.14 LE per dollar. The third time was in January 2002 as the losses in the tourism sector in Egypt continued, the CBE forced to devalue the Egyptian pound one more time and it set the ER at 4.5 LE per dollar. The CBE kept this rate till its announcement of adopting floating ER regime in January 2003. For more details of the developments in the exchange rate regimes in Egypt, see Massoud and Willett (2014).

Table (4) shows the estimations of the flexibility index for equations (3) and (4) over two periods. The first period starts on January 2003, when the Central Bank of Egypt announced the floating exchange rate regime, until December 2010, just before the 25th January revolution took place. According to regressions (1) and (3), the flexibility index was high in both cases. However, they were less than one which means that the Central Bank of Egypt did not freely float the 
exchange rate of the Egyptian pound.

The second period starts on January 2005, when the central bank announced its intention to implement inflation targeting as a monetary policy rule in Egypt once the requirements for this policy are met, and ends also on December 2010. As regressions (2) and (4) show, there was an increase in the flexibility index in both cases after the announcement of the Central Bank of Egypt regarding inflation targeting. These estimates are compatible with the IMF's classification of Egypt exchange rate regime in 2010 as a de facto managed floating exchange rate regime.

Table 4. Estimation of the Flexibility Index for Egypt

\begin{tabular}{lllll}
\hline Variable & $(1)$ & $(2)$ & $(3)$ & $(4)$ \\
\hline USD & $0.002^{* *}$ & 0.001 & $0.075^{* * *}$ & $0.091^{* * *}$ \\
& $(0.034)$ & $(0.962)$ & $(0.000)$ & $(0.000)$ \\
EURO & 0.001 & 0.003 & $0.089^{* * *}$ & $\left(0.009^{* * *}\right.$ \\
& $(0.523)$ & $(0.351)$ & $-0.000)$ & - \\
BP & 0.001 & -0.0002 & & $0.987 * * *$ \\
& $(0.657)$ & $(0.831)$ & $0.911 * * *$ & $(0.000)$ \\
EMP & $0.871 * * *$ & $0.975^{* * *}$ & $(0.000)$ & 0.0001 \\
C & $(0.000)$ & $(0.000)$ & -0.0002 & $(0.719)$ \\
& -0.0001 & -0.001 & $(0.778)$ & 72 \\
Observations & $(0.468)$ & $72.001)$ & 119 & 0.96 \\
Adj.R2 & 119 & 0.96 & 0.96 & 1.412 \\
DW & 0.89 & 0.893 & 1.477 & $2005 \mathrm{M} 1: 2010 \mathrm{M} 12$ \\
Sample & 0.740 & $2005 \mathrm{M} 1: 2010 \mathrm{M} 12$ & $2003 \mathrm{M} 1: 2012 \mathrm{M} 11$ & \\
\hline
\end{tabular}

* Statistically significant at 0.1 level, $* *$ Statistically significant at 0.05 level, $* * *$ Statistically significant at 0.01 level

Note: numbers in the parenthesis are the $\mathrm{p}$ - values

\subsubsection{Tunisia}

Tunisia had pegged the dinar to a basket of currencies until 1994. Between 1992 and 2000 Tunisia targeted the real exchange rate. Even though the de jure exchange rate regime is a managed float, the IMF's classifies its exchange rate as a crawling peg since 2012 and as stabilized arrangement in 2010 and 2012. For more details on Tunisia exchange rate regimes, see Brixiova, et al. (2013) and Fanizza et al. (2002).

For the Tunisian dinar, we estimated equations (3) and (4) over two periods, the first period starts on February 1999, as the data is available, and ends on September 2014. While the second period starts on January 2005, to capture the sharp depreciation of the dinar, and ends at the same date as the first period does.

We notice from regressions (1) and (2) that all coefficients, except for the constant term, are non-significant and the adj. R2 in both cases is very low. However, our estimates for equation (4), as regressions (3) and (4) show that the flexibility index in both cases was very small and non-significant, the same as in the estimates of equation (3). However, the coefficients for the dollar and for the euro are much higher and better explain the exchange rate regime in Tunisia. This is also compatible with the IMF's classification of the exchange rate regime in Tunisia from 2012 to 2014 as a de facto crawling peg. Also, we notice that there is a significant increase in adj. R2 values for equation (4) estimates comparing with the estimates of equation (5).

Table 5. Estimation of the Flexibility Index for Tunisia

\begin{tabular}{lllll}
\hline Variable & $(1)$ & $(2)$ & $(3)$ & $(4)$ \\
\hline USD & -0.028 & -0.008 & $0.395^{* * *}$ & $0.379^{* * *}$ \\
& $(0.804)$ & $(0.962)$ & $(0.000)$ & $(0.000)$ \\
EURO & 0.106 & 0.131 & $0.421 * * *$ & $0.450^{* * *}$ \\
& $(0.250)$ & $(0.351)$ & $(0.000)$ & - \\
BP & $0.119 * *$ & $0.134 * 000)$ \\
& $(0.012)$ & $(0.008)$ & & -0.001 \\
EMP & 0.005 & -0.001 & 0.003 & $(0.819)$ \\
& $(0.260)$ & $(0.867)$ & $(0.424)$ & $0.0001 * * *$ \\
C & $0.0001 * * *$ & $0.0001 * * *$ & $0.001 * * *$ & $(0.002)$ \\
& $(0.001)$ & 117 & $180.000)$ & 117 \\
Observations & 188 & 0.087 & 0.64 & 0.72 \\
Adj.R2 & 0.068 & 1.561 & 1.777 & 1.652 \\
DW & 1.650 & $2005 \mathrm{M} 1: 2014 \mathrm{M} 9$ & $1999 \mathrm{M} 2: 2014 \mathrm{M} 9$ & $2005 \mathrm{M} 1: 2014 \mathrm{M} 9$ \\
Sample & $1999 \mathrm{M} 2: 2014 \mathrm{M} 9$ & & \\
\hline
\end{tabular}

* Statistically significant at 0.1 level, $* *$ Statistically significant at 0.05 level, $* * *$ Statistically significant at 0.01 level

Note: numbers in the parenthesis are the $\mathrm{p}-$ values 


\subsection{Central and Eastern European Countries}

\subsubsection{Croatia}

Croatia presents a unique case due to the high degree of euroization in the Croatian economy. Thus, the Croatian economic policy strongly focuses on exchange rate stability. Since the end of the war of the early 1990s the exchange rate of the kuna was tightly pegged to the Deutsche mark from October 1994 to January 1, 1999. Since then, the kuna has been pegged to the euro. Even though the de jure exchange rate regime claimed by Croatian National Bank to be a managed float exchange rate regime, this does not stands along with the IMF's classification as crawling peg. For more details on the development of exchange rate regime of Croatia, see Kraft (2003).

For the Croatian kuna, as table (6) shows, the results of estimating equations (3) and (4) over two periods of time, before and after joining the EU, suggest that Croatian kuna is highly pegged to the euro. The flexibility index was very low in all regressions. As a matter of fact the coefficients of the euro were high and statistically significant for both equations over the two periods. However, we notice a decline in the euro coefficients after Croatia joined the EU on July 2013, as shown in regressions (2) and (4) comparing with its value before joining the EU. This is not compatible with the Croatian National Bank classifying its ER regime as a managed floating. According to the Croatian National Bank: "Croatia implements the exchange rate regime of managed floating, where the exchange rate of the domestic currency is not fixed against another foreign currency or basket of currencies, but is rather freely determined by the foreign exchange market. The exchange rate thus floats depending on the foreign exchange supply and demand on the foreign exchange market. However, the Croatian National Bank prevents too excessive exchange rate fluctuations by occasional market interventions in an attempt to maintain relative stability of the exchange rate", (Croatian National Bank, 2015).

As the flexibility index for all regressions is very low, our findings are compatible with the IMF's classification of the ER regime in Croatia from 2011 till the present which is a de facto crawling peg ER regime. This illustrates that the Croatian National Bank de jure exchange rate regime is not the de facto exchange rate regime that the country follows. The Croatian case presents a clear example of a country declaring following a flexible exchange rate regime, while its de facto exchange rate regime is much less flexible than the announced regime.

Table 6. Estimation of the Flexibility Index for Croatia

\begin{tabular}{|c|c|c|c|c|}
\hline Variable & (1) & (2) & (3) & (4) \\
\hline USD & $\begin{array}{l}0.064 \\
(0.501)\end{array}$ & $\begin{array}{c}0.181 \\
(0.615)\end{array}$ & $\begin{array}{c}0.009 \\
(0.684)\end{array}$ & $\begin{array}{c}0.106 \\
(0.253)\end{array}$ \\
\hline EURO & $\begin{array}{l}1.002 * * * \\
(0.000)\end{array}$ & $\begin{array}{c}0.957 * * * \\
(0.026)\end{array}$ & $\begin{array}{c}0.956 * * * \\
(0.000)\end{array}$ & $\begin{array}{l}0.880 * * * \\
(0.000)\end{array}$ \\
\hline BP & $\begin{array}{l}0.041 \\
(0.196)\end{array}$ & $\begin{array}{l}0.025 \\
(0.869)\end{array}$ & - & - \\
\hline EMP & $\begin{array}{l}0.079 * * * \\
(0.000)\end{array}$ & $\begin{array}{l}0.069 \\
(0.191)\end{array}$ & $\begin{array}{l}0.080 \\
(0.424)\end{array}$ & $\begin{array}{l}0.071 \\
(0.158)\end{array}$ \\
\hline $\mathrm{C}$ & $\begin{array}{c}0.0003 \\
(0.877)\end{array}$ & $\begin{array}{c}0.0005 \\
(0.377)\end{array}$ & $\begin{array}{c}0.0003 \\
(0.000)\end{array}$ & $\begin{array}{c}0.0005 \\
(0.366)\end{array}$ \\
\hline Observations & 138 & 16 & 138 & 16 \\
\hline Adj.R2 & 0.83 & 0.61 & 0.90 & 0.78 \\
\hline DW & 1.688 & 1.501 & 1.703 & 1.481 \\
\hline Sample & 2002M1:2013M6 & 2013M7:2014M10 & 2002M1:2013M6 & 2013M7:2014M10 \\
\hline
\end{tabular}

* Statistically significant at 0.1 level, ${ }^{* *}$ Statistically significant at 0.05 level, *** Statistically significant at 0.01 level

Note: numbers in the parenthesis are the $\mathrm{p}-$ values.

\subsubsection{Czech Republic}

Starting from May, 1993 till February, 1996, the Czech National (CNB) Bank followed a conventional fixed exchange rate regime against a basket of currencies. On February, 1996 till May, 1997 the koruna was allowed to fluctuate within a band of $+/-7 \%$. Through the period from May 1997 till January, 2009 the de jure exchange rate regime was managed float. During the period from January, 2009 till November, 2013, the de jure exchange rate regime was a managed float exchange rate regime. Finally, since the latter date, the CNB has been using the exchange rate as an instrument within its inflation targeting monetary policy. For more details on the Czech exchange rate regime, see Horvath and Jonas (1998), Begg (1998), and Josifidis, et al. (2009).

For the Czech koruna, we estimated the flexibility index before and after joining the EU in May 2004. For the first period from February 2002 to April 2004, the estimation results, as appear in regressions (1) and (3) in table (7), show that the flexibility index is quite high in both regressions. Its value was around 0.7 for the two regressions. Given that the official exchange rate regime during this period was the managed float, the values of the flexibility index are expected to be slightly higher than they are in our estimates. This suggests that the de facto regime in the Czech Republic during this period was less flexible than the de jure regime. 
Regarding the second period, after joining the EU till September 2014, our estimates for equations (3) and (4) show a decline in the flexibility index in both regressions. The values of the flexibility index were 0.65 and 0.63 in regressions (2) and (4), respectively. This means that in the second period the exchange rate regime that had been followed by the Czech National Bank was somewhat less flexible than before joining the EU. This also supported by the large increase in the euro coefficients in the second period compared with their values in the first period. This does not support the IMF's reclassification of the de facto Czech Republic exchange rate regime as de facto free floating regime in the years of 2010 to 2013. However, it stands along with the new exchange rate policy that the Czech National Bank put in effect in November 2013 when the CNB started to use the exchange rate as an instrument with its inflation targeting regime in the form known as one-sided exchange rate commitment.

Table 7. Estimation of the Flexibility Index for the Czech Republic

\begin{tabular}{|c|c|c|c|c|}
\hline Variable & (1) & (2) & (3) & (4) \\
\hline USD & -0.188 & -0.202 & $0.185^{*}$ & $0.126^{* *}$ \\
\hline EURO & $\begin{array}{l}(0.664) \\
0.398\end{array}$ & $\begin{array}{l}(0.139) \\
0.480 * * *\end{array}$ & $\begin{array}{c}(0.055) \\
0.703 * * *\end{array}$ & $\begin{array}{c}(0.004) \\
0.782 * * *\end{array}$ \\
\hline & $(0.279)$ & $(0.000)$ & $(0.000)$ & $(0.000)$ \\
\hline EMP & $0.709 * * *$ & $0.653 * * *$ & $0.712 * * *$ & $0.630 * * *$ \\
\hline $\mathrm{C}$ & -0.0001 & -0.0007 & -0.0001 & -0.0009 \\
\hline Observations & 27 & $(0.810)$ & $27.803)$ & 125 \\
\hline Adj.R2 & 0.86 & 0.87 & 0.85 & 0.89 \\
\hline DW & 1.625 & 2.205 & 1.567 & 2.140 \\
\hline Sample & 2002M2:2004M4 & 2004M5:2014M9 & 2002M2:2004M4 & 2004M5:2014M9 \\
\hline
\end{tabular}

$* \frac{\text { Statistically significant at } 0.1 \text { level, } * * \text { Statistically significant at } 0.05 \text { level, } * * * \text { Statistically significant at } 0.01 \text { level }}{}$

Note: numbers in the parenthesis are the $\mathrm{p}-$ values.

\subsubsection{Hungary}

During the period from 1990 to March 1995, an adjustable pegged exchange rate regime was in effect in Hungary, in which the exchange rate of the forint was pegged to a basket of foreign currencies whose composition and weighting were changed number of times. From March 1995 to September 2001, a crawling peg exchange rate regime was in place in Hungary. However, during this period the monetary authorities in Hungary set the HUF band to be $+/-2.5 \%$ on March 1995, then it widened this band to be +/- 15\% in early May 2001. Once the Euro introduced in January 1999, the Hungarian authorities changed the currency basket to include 70\% Euro and 30\% USD and in January 2000, the central parity was set in terms of Euro only. On October 2001 till February, 2008, a flexible peg of the forint to the euro within a fluctuation band was in place. The central parity of the band was set at 276.10 then reduced in early June 2003 by $2.3 \%$. Finally, on February 2008 up to date the monetary authorities in Hungary adopted a de jure floating exchange rate regime.

For the Hungarian forint, we estimated the flexibility index before and after joining the EU in May 2004. The estimation results for the first period that starts on October 2001, and ends on April 2004, show that the flexibility index was more than a unity in regression (1) and it was 0.99 in regression (3). This means that during this period the Central Bank of Hungary is freely float the exchange rate of the forint. This is supported by the very low coefficients for all currencies and the high adj. R2 values. After joining the EU, we notice that the flexibility index was still high. However a slight decline in its values took place when we estimated equation (4), as reported in both regressions (3) and (4). Our findings fit the de jure ER in Hungary and its de facto classification by the IMF from 2010 to 2014 as a floating exchange rate regime.

Table 8. Estimation of the Flexibility Index for Hungary

\begin{tabular}{lllll}
\hline Variable & $(1)$ & $(2)$ & $(3)$ & $(4)$ \\
\hline USD & -0.101 & 0.008 & 0.457 & $0.458^{* * *}$ \\
& $(0.138)$ & $(0.717)$ & $(0.000)$ & $0.000)$ \\
EURO & -0.072 & $0.052^{*}$ & & $0.489^{* * *}$ \\
& $(0.2474)$ & $(0.034)$ & $0.413^{* * *}$ & $(0.000)$ \\
BP & -0.033233 & -0.004 & - & - \\
& $(0.3364)$ & $(0.617)$ & & $0.970^{* * *}$ \\
EMP & $1.008^{* * *}$ & $1.009 * * *$ & $0.987 * * *$ & $(0.000)$ \\
& $(0.000)$ & $(0.000)$ & $(0.000)$ & -0.0004 \\
C & 0.0006 & -0.0007 & 0.001 & $(0.966)$ \\
& $(0.6397)$ & $(0.810)$ & $(0.4489)$ & 125 \\
Observations & 31 & 125 & 31 & 0.99 \\
Adj.R2 & 0.99 & 0.99 & 0.98 & 1.520 \\
DW & & 1.953 & 2.179 &
\end{tabular}


Sample 2001M10:2004M4

2004M5:2014M9

2001M10:2004M4

2004M5:2014M9

* Statistically significant at 0.1 level, ** Statistically significant at 0.05 level, *** Statistically significant at 0.01 level

Note: numbers in the parenthesis are the $\mathrm{p}$ - values.

4.2.4 Poland

From January 1990 to October 1991, the de jure exchange rate regime of Poland was a conventional fixed pegged exchange rate against the dollar then against a basket of currencies. On October 1991 till May 1995, Poland changed its de jure exchange rate regime to be a crawling pegged exchange rate against the dollar then against a basket of currencies. Through the period from May 1995 to April 2000, the authorities followed a crawling band exchange rate with a corridor of +/- 7\%. Finally, starting from April 2000 up to date the de jure exchange rate is a free floating exchange rate regime. For more details on Poland's exchange rate regime, see Josifidis, et al. (2009).

For the Polish zloty, we estimated the flexibility index after joining the EU in May 2004. Because of data availability, we could not estimate the flexibility index for the Polish zloty before May 2004. As table (9) shows, the flexibility index for the estimates of both equation (3) and equation (4) was unexpectedly low. What makes the case of Poland is even more interesting that the coefficients for the euro were extremely high. They were 1.534 and 1.128 for regressions (2) and (4), respectively. This suggests that the Narodowy Bank Polski acts aggressively to prevent the excessive exchange rate fluctuations by intervening the foreign exchange market in order to keep the value of the zloty stable in relation with the euro.

This finding stands in contrast with both the de jure free floating exchange rate regime reported by Narodowy Bank Polski and with the de facto free floating's classification of Poland exchange rate regime by the International Monetary Fund. One may explain the low flexibility index for the Polish zloty by arguing that even though the National Bank has implemented a free floating regime for the zloty, big accumulations and losses of official reserves took place in a way that is separate of what was going on with the zloty, and that by chance it looks like lining against the wind intervention. Frankel and Wei provided other explanations for a similar case regarding the Australian dollar. They argued that: "The problem may be that reserves are measured as more variable than seems right. Or the problem may be endogeneity of the Exchange Market Pressure variable", Frankel and Wei (2009).

Table 9. Estimation of the Flexibility Index for Poland

\begin{tabular}{lllll}
\hline Variable & $(1)$ & $(2)$ & $(3)$ & $(4)$ \\
\hline USD & - & 0.103 & - & $-0.382^{* * *}$ \\
& & $(0.764)$ & $(0.000)$ \\
EURO & - & $1.536^{* * *}$ & $\left(.128^{* * *}\right.$ \\
& - & $(0.000)$ & - & $-0.000)$ \\
BP & - & $\left(0.306^{* * *}\right.$ & - & 0.005 \\
& - & 0.002 & - & $(0.937)$ \\
EMP & - & $(0.916)$ & - & -0.0004 \\
C & -0.0005 & $-537)$ \\
Observations & - & $(0.537)$ & - & 126 \\
Adj.R2 & - & 126 & - & 0.46 \\
DW & - & 0.49 & - & 1.375 \\
Sample & - & 1.419 & - & $2004 \mathrm{M} 5: 2014 \mathrm{M} 10$ \\
\hline
\end{tabular}

*** Statistically significant at 0.01 level

Note: numbers in the parenthesis are the $\mathrm{p}$ - values.

4.2.5 Romania

Marcu (2008) summarized the exchange rate regime of Romania as follows: "Romania has started with a fixed exchange rate regime and moved gradually from an intermediate (soft peg) regime to a managed floating regime. Now the national currency has a managed floating exchange rate against euro. Since November 2004, Romania has developed a new approach concerning the operational exchange rate strategy, characterized by:

- a greater flexibility of the exchange rate in the context of maintaining the managed-floating regime;

- a greater role of the market in the process of determining the exchange rate;

- less frequent interventions of the National Bank of Romania (NBR) in the foreign exchange market."

According to the National Bank of Romania, the de jure exchange rate regime of the leu is a managed float. This in line with using inflation targeting as a framework for the monetary policy in which allows for a flexible policy response to unpredicted shocks.

Finally, regarding our estimates of the flexibility index, the estimates of equations (3) and (4) are reported in table (10). During the period before joining the EU on January 2007, Romania had taken serious steps to make its exchange rate 
regime more flexible. However, as regressions (1), (2), (3), and (4) show, the flexibility index values were very low. This again a similar case as Poland, where our estimates get in contrast with both the National Bank of Romania (NBR) and the IMF classification of Romania's exchange rate regime as they both classified it as floating ER regime.

Table 10. Estimation of the Flexibility Index for Romania

\begin{tabular}{|c|c|c|c|c|}
\hline Variable & (1) & (2) & (3) & (4) \\
\hline USD & 0.457 & $1.210 * * *$ & $0.187 * *$ & $-0.145^{* *}$ \\
\hline & $(0.417)$ & $(0.000)$ & $(0.096)$ & $(0.054)$ \\
\hline EURO & 0.686 & $1.975 * * *$ & $0.447 * *$ & $0.892 * * *$ \\
\hline $\mathrm{BP}$ & $\begin{array}{l}(0.189) \\
0.459 *\end{array}$ & $\begin{array}{l}(0.000) \\
0.353 * * *\end{array}$ & ${ }_{-}(0.016)$ & $(0.000)$ \\
\hline & $(0.099)$ & $(0.000)$ & & \\
\hline EMP & $\begin{array}{l}.002 \\
(0.852)\end{array}$ & $\begin{array}{l}0.005 \\
(0.546)\end{array}$ & $\begin{array}{l}.002 \\
(0.820)\end{array}$ & $\begin{array}{l}0.007 \\
(0.447)\end{array}$ \\
\hline $\mathrm{C}$ & 0.0007 & 0.0008 & 0.0006 & 0.0009 \\
\hline Observations & $(0.460)$ & (0.196) & $(0.517)$ & $(0.184)$ \\
\hline Adj.R2 & 0.05 & 062 & 00 & 94 \\
\hline $\mathrm{DW}$ & 1.006 & 1.629 & 1.044 & 1.667 \\
\hline Sample & 2002M1:2006M12 & $2007 \mathrm{M} 1: 2014 \mathrm{M} 10$ & 2002M1:2006M12 & 2007M1:2014M10 \\
\hline
\end{tabular}

** Statistically significant at 0.05 level, *** Statistically significant at 0.01 level

Note: numbers in the parenthesis are the $\mathrm{p}$ - values

\section{Conclusion}

In this paper we estimated the flexibility index for the North African countries with following findings. Our estimate of the flexibility index for Algeria goes along with the de jure exchange rate that is announced by the Central Bank of Algeria as it declares that it intervenes in the foreign exchange market in order to stabilize the real effective exchange rate of the dinar. Our estimates also go along with the IMF classification of the exchange rate regime of Algeria as "other managed arrangement against composite". For Egypt, the flexibility index estimates indicate that the de jure free floating exchange rate that as announced by the Central Bank of Egypt has not been preserved. Our results also indicate that the central bank is moving toward a more flexible exchange rate regime. Finally, our findings support the IMF's classification of the exchange rate regime in Egypt as stabilized arrangement. For Tunisia, while the de jure exchange rate regime is managed floating, our estimates goes against this classification. The flexibility index for the Tunisian exchange rate regime is very low. However, our findings supports the IMF's classification of the exchange rate regime in Tunisia as "Crawl-Like Arrangement". Thus, for the Northern African countries our estimates supports the IMF's Classifications of the exchange rate regimes in these countries. However, even though our estimates supports the de jure exchange rate regime in Algeria, they indicate a divergent between the de jure and the de facto exchange rate regimes in Egypt. In Tunisia, this divergence between the de jure and de facto exchange rate regime is substantial.

Regarding the Central and Eastern European countries, our findings are the following. Our estimates of the flexibility index for Croatia indicate that the de jure managed floating exchange rate regime announced by the Croatian National Bank has not been preserved. However, our findings support the IMF's classification of the exchange rate regime in Croatia as a de facto crawling peg. Our estimates also indicate that there is no substantial difference in the de facto exchange rate regime in Croatia before and after joining the EU. For the Czech Republic, our estimates of the flexibility index do not support both the de jure exchange rate regime announced by the Czech National Bank and the IMF's classification of this regime as a free floating exchange rate regime between 2010 and 2013. The IMF's reclassification of the exchange rate regime of the Czech Republic in 2014 to be a de facto managed floating supports our findings. Moreover, our estimates show that the exchange rate regime of the Czech Republic is slightly less flexible after joining the EU. For Hungary, our estimates of the flexibility index have high values supporting both the de jure and the IMF's classification of the exchange rate regime as a floating exchange rate. Moreover, our estimates indicates that there is no change in the exchange rate regime in Hungary after joining the EU. For Poland and Romania, the flexibility index estimates are very low which stands in contrast with both the de jure and the IMF's classification of the exchange rate regimes as free floating and floating exchange rate regime for Poland and Romania, respectively. Thus, our findings go along with the de jure exchange rate regime only for Hungary. Also, our findings go along with the IMF's classifications of the exchange rate regime in Croatia. However, our estimations of the flexibility index stand in contrast with the IMF's classifications for the Czech Republic, Poland, and Romania. This indicates that more studies are needed to be conducted regarding the exchange rate regimes of the latter countries.

\section{References}

Babula, A., \& Otker-Robe, I. (2002). The Evolution of Exchange Rate Regimes Since 1990: Evidence from De Facto Policies. IMF Working Paper Series, WP/02/155.

Begg, D. (1998). Pegging Out: Lessons from the Czech Exchange Rate Crisis. Journal of Comparative Economics, 26, 669-690. 
Brixiova, Z., Egert, B., and Essid, T. H. A. (2013). The Real Exchange Rate and External Competitiveness in Egypt, Morocco and Tunisia. Institute for the Study of Labor, IZA DP, 7822.

Calvo, G. A., \& Mishkin, F.S. (2003).The Mirage of Exchange Rate Regimes for Emerging Market Countries. NBER Working Paper, 9808.

Calvo, G., \& Reinhart, C. M. (2002). Fear of Floating. Quarterly Journal of Economics, CXVII, 2, 379-408.

Eichengreen, B. (1994). International Monetary Arrangements for the 21st Century. The Brookings Institution, D.C.

Fanizza, D., Laframboise, N., Martin, E., Sab, R., \& Karpowicz, I. (2002). Tunisia's experience with real exchange rate targeting and the Transition to a Flexible Exchanger Rate Regime. IMF Working Papers Series.

Frankel, J. A., \& Wei, S. (2008). Estimation of De Facto Exchange Rate Regimes: Synthesis of the Techniques for Inferring Flexibility and Basket Weights. NBER Working Paper, 14016.

Frankel, J. A., Fajnzylber, E., Schmukler, S. L., \& Serven, L. (2001). Verifying Exchange Rate Regimes. Journal of Development Economics, 66, 351-386.

Guisinger, A., \& Singer, D.A. Exchange Rate Proclamations and Inflation-Fighting Credibility. Mimeo at Notre Dame web page, http://www3.nd.edu/ aguising/Papers/IO_Guisinger_Singer_final.pdf

Horvath J., \& Jonas, J. (1998). Exchange Rate Regimes in the Transition Economies, Case Study of the Czech Republic: 1990-1997. Center for European Integration Studies, ZEI, University of Bonn, 1998, B 11

Horvath, J. (2006). "International Currency Arrangements and Policies” Nova Science Publishers, New York.

International Monetary Fund (2014). Algeria Financial System Stability Assessment. Country Report.

International Monterey Fund 2014). The annual report on exchange arrangements and exchange restrictions.

Josifidis, K., Allegret, J., \& Pucar, E.B. (2009). Monetary and Exchange Rate Regimes Changes: The Cases of Poland, Czech Republic, Slovakia and Republic of Serbia. PANOECONOMICUS, 2, 199-226. http://dx.doi.org/10.2298/PAN0902199J

Koranchelian, T. (2005). The Equilibrium Real Exchange Rate in a Commodity Exporting Country: Algeria's Experience. IMF Working Paper series.

Kraft, E. (2003). Monetary Policy under Dollarization: The Case of Croatia. Comparative Economic Studies, 45, 256-277.

Levy-Yeyati, E., \& Sturzenegger, F. (2005). Classifying Exchange Rate Regimes: Deeds vs. Words. European Economic Review, 49, 1603-1635.

Marcu, N. (2008). Romania's Exchange Rate Policy Towards its European Monetary Union Membership-Prospects and Challenges. Romanian Journal of Economic Forecasting.

Massoud, A., \& Willett, T. (2014). Egypt's Exchange Rate Regime Policy after the Float. International Journal of Social Science Studies, 2(4), October, 2014. http://redfame.com/journal/index.php/ijsss/article/view/445

Reinhart, C., \& Rogoff, K. (2004). The Modern History of Exchange Rate Arrangements: A Reinterpretation. Quarterly Journal of Economics, 119, 1-48.

Willett, T., Chiu, M. P., Dechsakulthorn, S., Ghosh, R., Kibesse, B., Kim, K., Kim, Y., \& Ouyang, A. (2011). Classifying international aspects of currency regimes. Journal of Financial Economic Policy, 3, 288-303.

\section{(cc) EY}

This work is licensed under a Creative Commons Attribution 3.0 License. 